\title{
PENDIDIKAN ISLAM DAN PENGUATAN MASYARAKAT SIPIL MELALUI CIVIC EDUCATION
}

\author{
Kisbiyanto \\ STAIN Kudus, Jawa Tengah, Indonesia \\ kisbiyanto@gmail.com
}

\begin{abstract}
ISLAMICEDUCATIONAND CIVIL SOCIETY REINFORCEMENT THROUGH CIVIC EDUCATION: Studies on Islam and Indonesia is very important for Muslims as civil society in Indonesia. Nowadays, the muslim community has many challenges to be good Muslims and citizens. Everyone has the right to select the appropriate choice, but the best way out instead of breaking religion and State. Islamic religious colleges have a responsibility to unite the studies about Islam and Indonesia. Lecturers should teach how to unite the research about Islam and Indonesia. This study describes the concept of the curriculum and courses for strengthening the civil society. The study was designed using qualitative approach. The data were collected from interviews, observation, and documents. Validity and reliability were tested using a test of credibility, transferability, dependability, and confirmability. Data were analyzed by the interactive model. The result states that there are six matters which consist of civic education, tolerance, and social. They are Pancasila and civic education, methodology of Islamic studies, Indonesian language, comparation of religions, tasawuf or Islamic Sufism and Islamic practicum. The learning refers to the system of national qualification framework of Indonesia and national standard of higher education. The structure and content of the Islamic education curriculum contains of elements of civic education and adapts to the national college standard so that the system becomes a virtue value that Islamic education is in line with the ideology of nationalism and the civil society reinforcement in Indonesia.
\end{abstract}

Keywords: Islamic Education, Civil Society, Civic Education 


\begin{abstract}
Abstrak
Studi tentang Islam dan Indonesia sangat penting bagi muslim sebagai masyarakat sipil di Indonesia. Sekarang ini, masyarakat muslim mempunyai banyak tantangan untuk bisa menjadi muslim dan warga negara yang baik. Setiap orang memang mempunyai hak untuk memilih sesuai pilihannya, tetapi jalan keluar terbaik bukan dengan cara memisahkan agama dan negara. Perguruan tinggi keagamaan islam mempunyai tanggung jawab untuk menyatukan kajian keislaman dan keindonesiaan. Para dosen seharusnya mengajarkan bagaimana menyatukan kajian Islam dan kajian tentang Indonesia. Penelitian ini menjelaskan tentang konsep kurikulum dan mata kuliah untuk penguatan masyarakat sipil. Penelitian ini dirancang dengan pendekatan kualitatif. Data dikumpulkan dengan wawancara, observasi, dan studi dokumen. Validitas dan reliabilitas diuji dengan uji kredibilitas, transferabilitas,depenabilitas, dan konfirmabilitas. Data dianalisis dengan model interaktif. Hasil penelitian menyatakan bahwa ada enam mata kuliah yang memuat pendidikan sipil, toleransi, dan keharmonisan sosial, yaitu pendidikan Pancasila dan kewarganegaraan, metodologi studi Islam, bahasa Indonesia, perbandingan agama, tasawuf atau kajian sufi Islam, dan praktikum ibadah. Adapun pembelajarannya mengacu pada sistem kerangka kualifikasi nasional Indonesia dan standar nasional pendidikan tinggi. Struktur dan konten kurikulum pendidikan Islam memuat unsur pendidikan kewarganegaraan serta menyesuaikan dengan strandar nasional perguruan tinggi sehingga sistem ini menjadi nilai keutamaan bahwa pendidikan Islam sejalan dengan ideologi nasionalisme dan penguatan masyarakat sipil di Indonesia.
\end{abstract}

Kata Kunci: Pendidikan Islam, Masyarakat Sipil, Civic Education

\title{
A. Pendahuluan
}

Pengembangan ilmu dan pengetahuan sosial terus dilakukan oleh banyak ilmuwan, termasuk di lingkungan perguruan tinggi keagamaan Islam di Indonesia. Dewasa ini, program kajian keislaman mempunyai nilai strategis di tengahtengah tantangan untuk mengatasi masalah kebangsaan dan kenegaraan. Sebagaimana terjadinya berbagai tindak dan kejadian yang berakibat penentangan kepada paham negara dan bangsa Indonesia, misalnya terorisme, paham radikalisme agama, antiPancasila, bahkan cita-cita pendirian negara khilafah. Pendidikan 
seperti menjadi salah satu pihak yang paling dipersalahkan, atau setidaknya dituntut pertanggungjawabannya atas beredarnya ideologi dan gerakan yang anti paham negara dan kebangsaan yang berlaku di Indonesia.

Dalam konteks kehidupan beragama Islam, masyarakat muslim sebagai komunitas terbesar di Indonesia juga mendapat tantangan yang sangat besar, terkait dengan adanya gerakan Islam yang radikal dan apalagi yang mengancam keutuhan berbangsa dan bernegara di Negara Kesatuan Republik Indonesia. Islam di Indonesia seperti bisa dikelompokkan dalam tiga ranah, yaitu Islam kiri yang sering dialamatkan kepada Islam liberal, Islam kanan yang dialamatkan kepada Islam radikal, dan Islam moderat yang dialamatkan kepada Islam yang nasionalis yang memperjuangkan Islam dalam bingkai kehidupan Negara Kesatuan Republik Indonesia. Islam menjadi bagian penting perikehidupan berbangsa dan bernegara di Indonesia karena di samping Islam menjadi agama mayoritas penduduk di Indonesia, Islam juga adalah menjadi ideologi dunia yang secara dinamis berkembang dalam berbagai bidang misalnya politik (siyasah) termasuk bentukbentuk relasi Islam dengan berbagai bentuk negara baik kerajaan, republik, maupun lainnya, juga bidang ekonomi (iqtishadiyah), termasuk ekonomi syariah, perbankan syariah, islamic finance, dan lainnya, serta bidang-bidang kehidupan lain seperti pendidikan, dan perkembangan ilmu pengetahuan dan teknologi.

Islam di Indonesia secara demografis menjadi agama terbesar, dengan pemeluk lebih dari $86 \%$ dari seluruh penduduk sekitar 235 juta jiwa. Artinya, komunitas mayoritas itu mempunyai kekuatan politik dan ekonomi yang besar. Jumlah mayoritas itu juga menjadi skala prioritas dalam pembangunan berbanga dan bernegara. Karena itu, Pemerintah Indonesia mempunyai Kementerian Agama RI yang mengurusi tentang urusan keagamaan (ministry of religious affair), dengan pilar-pilar pada bidang pembinaan dan kerukunan umat beragama, pendidikan agama, dan urusan haji dan umroh, selain bidang urusan masingmasing agama lainnya. Itu salah satu dari sistem kebijakan nasional yang berlaku di Indonesia sebagai wujud dari prioritas mayoritas muslim. Dalam bidangf pendidikan, selain taman kanak-kanak 
(TK), sekolah dasar (SD), sekolah menengah pertama (SMP), sekolah menengah atas (SMA), sekolah menengah kejuruan (SMK), dan perguruan tinggi pada umumnya, maka Pemerintah Republik Indonesia juga mempunyai kebijakan nasional dengan berdiri dan terselenggaranya pendidikan formal berciri keagamaan, yaitu raudlatul athfal (RA), madrasah ibtidaiyah (MI), madrasah tsanawiyah (MTs), madrasah aliyah (MA), sekolah tinggi agama Islam negeri (STAIN), institut agama Islam negeri (IAIN), dan universitas Islam negeri (UIN). Belum lagi kebijakan nasional yang menjamin penegakan hukum agama Islam melalui penyelenggaraan sistem peradilan Islam dengan adanya pengadilan agama (PA) di tingkat kabupaten/kota, pengadilan tinggi agama (PTA) di tingkat provinsi, serta Mahkamah Agung yang juga melayani persidangan perihal urusan agama Islam. Pembinaan umat Islam juga dari Kementerian Agama RI hingga kantor wilayah Kementerian Agama di setiap provinsi dan kantor Kementerian Agama di setiap kabupaten/kota, bahkan sampai di tingkat kecamatan juga ada lembaga resmi keagamaan, yaitu Kantor Urusan Agama (KUA). Artinya, bahwa perikehidupan berbangsa dan bernegara di Indonesia sudah baik, terutama dalam kaitannya dengan kehidupan beragama. Mayoritas muslim mendapatkan prioritas-prioritas yang semestinya dari negara, sedangkan minoritas lainnya juga tetap terjamin keberadaan dan kehidupan keagamaan mereka. Negara memberikan proporsi dan perlakuan yang tepat pada semua pemeluk agama di Indonesia.

Namun, idealitas tersebut bukan tanpa kendala dan tantangan. Kendala kehidupan beragama Islam berasal dari internal Islam sendiri, yaitu adanya paham-paham keislaman yang menyimpang dan juga menentang keberadaan Negara Kesatuan Republik Indonesia, bahkan terekspresikan dengan gerakan radikal semacam terorisme yang menggunakan kekerasan atas nama agama Islam, dan juga paham memberontak dengan ingin mendirikan negara Islam, atau bentuk lainnya sehingga paham itu sama dengan ingin meruntuhkan sistem negara yang sekarang sudah berjalan. Tantang berasal dari eksternal Islam, yaitu bahwa politik, ekonomi, dan ideologi dunia serta ilmu pengetahuan dan teknologi yang sekarang selalu mengalami dinamika dan 
perubahan-perubahan yang juga berdampak pada sistem politik, ekonomi, dan paham-paham yang ada di Indonesia. Karena itu, Kementerian Agama yang membidangi urusan keagamaan mempunyai kendala dan tantangan itu sehingga keberadaan dan perannya harus menunjukkan nilai strategis untuk mengantisipasi dan mengatasi masalah kebangsaan dan kenegaraan yang terkait dengan agama. Nilai strategis itu adalah pendidikan Islam harus bisa berperan penting untuk menanamkan nilai-nilai keislaman untuk menjadi bagian penting penguatan nilai-nilai keindonesian. Islam dan negara dipersatukan dalam harmoni kehidupan bagi rakyatnya, dan bukan menjadi pertentangan yang menghancurkan sendi-sendi kemanusiaan dalam bentuk teror yang berarti kekerasan dengan mengatasnamakan agama Islam, dan juga pemberontakan terhadap sistem negara atas nama penegakan agama Islam.

Peran pendidikan Islam di bawah naungan Kementerian Agama sebagai pemerintah sebenarnya sangat besar terutama jika dilihat dari persebaran lembaga pendidikan keagamaan di Indonesia, misalnya madrasah, pondok pesantren, dan perguruan tinggi keagamaan Islam. Tiga pilar pendidikan Islam ini telah memerankan fungsinya sebagai lembaga yang menanamkan nilai-nilai keislaman bersamaan dengan nilai-nilai keindonesiaan. Kontribusi pendidikan Islam melalui tiga pilar kelembagaan pendidikan Islam itu perlu mendapat perhatian lebih lanjut agar benar-benar menjadi program utama pendidikan keagamaan yang relevan dengan nilai-nilai kebangsaan di Indonesia. Salah satu bentuk pendidikan tersebut melalui pendidikan tinggi yang terprogram dalam struktur kurikulum dan pembelajaran di semua program studi keagamaan. Baik, studi tentang ushuluddin, syariah, tarbiyah, dakwah, maupun adab di STAIN, IAIN, dan UIN dipastikan mengajarkan metodologi studi Islam yang bercorak nusantara yang moderat, dan juga mengajarkan pendidikan kewarganegaraan yang berisi nilai-nilai keindonesiaan.

Model yang digunakan dalam penelitian ini adalah studi kasus, yaitu salah satu bentuk penelitian kualitatif sebagaimana disebutkan oleh McMillan (2001:29) bahwa penelitian dengan pendekatan kualitatif mempunyai beberapa model, yaitu 
etnografi, fenomenologi, studi kasus, grounded theory, critical studies, concept analysis dan historical analysis. Karakter utama dari pendekatan kualitatif adalah untuk mengungkapkan fenomena dan realitas melalui data-data, bukan untuk menguji keberlakuan suatu teori. Data-data spesifik dicari maknanya untuk membuat simpulan yang general dari makna-makna yang diperoleh dari data-data tersebut. Penelitian ini dirancang untuk menjelaskan tentang konsep materi ajar dan pembelajaran pendidikan Islam terkait dengan penguatan masyarakat sipil melalui civic education. Pertimbangan utama dalam menentukan subyek penelitian ini adalah kesesuaian antara sumber informasi yang terkait dengan permasalahan penelitian. Sumber informasi dikelompokkan menjadi dua, yaitu sumber utama terdiri dari pengelola dan dosen yang menjadi pelaku utamanya, dan sumber pendukung, yaitu sumber dokumentasi dan arsip-arsip yang relevan. Penelitian harus memperoleh data yang terpercaya, karena itu sumber informasi diperoleh dari para responden yang bisa memberikan data yang akurat, dan dokumen yang sesuai dengan kenyataan. Penelitian harus memperoleh kesesuaian antara persoalan yang difokuskan dengan setting penelitian, sebagaimana dianjurkan oleh Moleong (1994:19), maka dilakukan penjajakan dan penilaian data-data. Demikian juga pengambilan data melalui dokumen dilakukan untuk mendapatkan informasi dari sumber yang berupa arsip dan naskah akademik yang relevan. Data diperoleh dari dokumentasi data-data yang berkaitan dengan pembelajaran bernuansa penguatan masyarakat sipil melalui civic education. Pengecekan keabsahan data menggunakan empat kriteria Moleong (2001:78) dan Sugiyono (2008:367), yaitu derajat kepercayaan (credibility), keteralihan (transferablity), kebergantungan (dependability) dan kepastian (confirmability). Kriteria itu menjadikan data terverifikasi dan teruji secara ilmiah sehingga menambah keteryakinan data. Data yang sudah teruji dengan baik menjadikan penelitian semakin memiliki kesimpulan yang terpercaya pula. Data yang diperoleh kemudian diverifikasi, disimpulkan dan agar dapat dipertanggungjawabkan secara ilmiah, maka dilakukan pemeriksaan keabsahan data. Teknik yang digunakan dalam pemeriksaan keabsahan data dalam penelitian meliputi: perpanjangan keikutsertaan, ketekunan pengamatan, 
triangulasi, pemeriksaan sejawat, kecukupan referensi, kajian kasus negatif dan pengecekan. Namun, dalam penelitian ini, tidak semua teknik digunakan, hanya beberapa teknik yang tepat dan diperlukan saja yang digunakan, khususnya trianggulasi. Triangulasi dimaksudkan untuk mendapatkan keabsahan data yang sahih dan terpercaya sehingga bisa digunakan sebagai penyimpulan yang benar sebagaimana disarankan oleh Sugiyono (2008:372) dan Bungin (2003:78). Analisis data merupakan proses mencari dan mengatur secara sistematis transkrip wawancara, catatan lapangan, dan bahan-bahan lain yang telah dihimpun untuk menambah pemahaman mengenai bahan-bahan penelitian untuk memungkinkan mendapat temuan sebagai hasil penelitian (Bogdan 1990:107). Untuk memberikan pemaknaan atas data atau fenomena yang ditemukan dan dikumpulkan dalam penelitian ini, maka dilakukan analisis dengan pendekatan kualitatif dengan eksplanasi bersifat deskripsi. Selanjutnya datadata yang diperoleh dianalisis dengan model siklus interaktif sebagaimana dikemukakan oleh Milles dan Huberman (1992:20). Proses ini dilakukan selama proses penelitian ditempuh melalui serangkaian proses pengumpulan, reduksi, penyajian dan verifikasi data. Teknis analisis model Miles ini berbeda dengan misalnya model analisis menurut Ryan dan Bernard dalam Denzin (2000:377) menjelaskan bahwa teknis analisis data dalam domain kultural (techniques for analyzing data about cultural domain) menggunakan analisis komponensial, taksonomi dan mental maps. Peneliti melakukan menentukan simpulan atau verifikasi, setelah terlebih dahulu melihat hubungan satu dengan yang lain dalam kesatuan bahasan tentang vahan ajar konten penguatan masyarakat sipil melalui civic education.

\section{B. Pembahasan}

Penelitian ini dilaksanakan untuk menjelaskan bagaimana konten materi ajar kewarganegaraan, dan bagaimana pembelajarannya di Tarbiyah Sekolah Tinggi Agama Islam Negeri Kudus. Perguruan tinggi keagamaan Islam negeri berjumlah 56 di seluruh Indonesia, satu di antaranya adalah Sekolah Tinggi Agama Islam Negeri Kudus. Sekolah Tinggi Agama Islam Negeri Kudus 
(STAIN) didirikan pada tanggal 21 Maret 1997, dengan membuka 2 program studi, yaitu Program Studi Pendidikan Agama Islam (PAI) dan Ahwal Syahshiyah (AS). Pengembangan program studi di STAIN Kudus hingga tahun 2016/2017 mencapai 29 program studi. Mahasiswa yang belajar di kampus ini sekitar 12.000 orang dengan berbagai latar belakang, yang pada umumnya adalah masyarakat muslim di Jawa Tengah bagian timur. Sebagian kecil lainnya berasal dari daerah lain termasuk luar Jawa. Salah satu yang diunggulkan di kampus ini adalah kajian keislaman yang mengedepankan kajian kontekstual dari pada tekstual, termasuk mengedepankan integrasi keilmuan Islam dengan lintas disiplin dan harmonisasi Islam dan keindonesiaan. Kepastian keberpihakan STAIN Kudus menyusun kurikulum dan pembelajarannya didasarkan pada regulasi negara, yaitu Undang-Undang Republik Indonesia No 20 tahun 2003 tentang Sistem Pendidikan Nasional, Undang-Undang Republik Indonesia No 14 tahun 2005 tentang Guru dan Dosen, Undang-Undang Republik Indonesia No 12 tahun 2012 tentang Pendidikan Tinggi, Peraturan Presiden Nomor 8 Tahun 2012 tentang Kerangka Kualifikasi Nasional Indonesia, Peraturan Menteri Pendidikan dan Kebudayaan Nomor 73 Tahun 2013 tentang Penerapan Kerangka Kualifikasi Nasional Indonesia Bidang Pendidikan Tinggi, Peraturan Menteri Riset, Teknologi, dan Pendidikan Tinggi Nomor 44 Tahun 2015 tentang Standar Nasional Pendidikan Tinggi, Peraturan Menteri Agama Nomor 33 Tahun 2016 tentang Gelar Akademik Perguruan Tinggi Keagamaan, dan Peraturan Menteri Agama Nomor 1 Tahun 2016 tentang Ijazah, Transkrip Nilai, dan Surat Keterangan Pendamping Ijazah. Sesuai dengan ideologi Negara dan budaya Bangsa Indonesia, maka implementasi sistem pendidikan nasional dan sistem pelatihan kerja yang dilakukan di Indonesia pada setiap level kualifikasi pada KKNI mencakup proses yang membangun karakter dan kepribadian manusia Indonesia sebagai berikut: (1) bertakwa kepada Tuhan Yang Maha Esa, memiliki moral, etika dan kepribadian yang baik di dalam menyelesaikan tugasnya, (2) berperan sebagai warganegara yang bangga dan cinta tanah air serta mendukung perdamaian dunia, (3) mampu bekerjasama dan memiliki kepekaan sosial dan kepedulian yang tinggi terhadap masyarakat dan lingkungannya, 
menghargai keanekaragaman budaya, pandangan, kepercayaan, dan agama serta pendapat/temuan original orang lain, dan (5) menjunjung tinggi penegakan hukum serta memiliki semangat untuk mendahulukan kepentingan bangsa serta masyarakat luas. Lulusan program sarjana wajib memiliki keterampilan umum sesuai Standar Nasional Pendidikan Tinggi yaitu (1) mampu menerapkan pemikiran logis, kritis, sistematis, dan inovatif dalam konteks pengembanagn atau implementasi ilmu pengetahuan dan teknologi yang memperhatikan dan menerapkan nilai humaniora yang sesuai dengan bidang keahliannya, (2) mampu menunjukkan kinerja mandiri, bermutu dan terukur, (3) mampu mengkaji implikasi pengembangan atau implementasi ilmu pengetahuan teknologi yang memperhatikan dan menerapkan nilai humaniora sesuai dengan keahliannya berdasarkan kaidah, tata cara dan etika ilmiah dalam rangka menghasilkan solusi, gagasan, desain atau kritik seni, menyusun deskripsi saintifik hasil kajiannya dalam bentuk skripsi atau laporan akhir, dan mengunggahnya dalam laman perguruan tinggi, (5) menyusun deskripsi saintifik hasil kajian tersebut di atas dalam bentuk skripsi atau laporan tugas akhir dan menggunggah dalam laman perguruan tinggi, (6) mampu mengambil keputusan secara tepat dalam konteks penyelesaian masalah di bidang keahliannya, berdasarkan hasil analisis informasi dan data, (7) mampu memelihara dan mengembangkan jaringan kerja dengan pembimbing, kolega, sejawat baik di dalam maupun di luar lembaga, (8) mampu bertanggung jawab atas pencapaian hasil kerja kelompok dalam melakukan supervisi dan evaluasi terhadap penyelesaian pekerjaan yang ditugaskan kepada pekerja yang berada di bawah tanggung jawabnya, (9) mampu melakukan proses evaluasi diri terhadap kelompok kerja yang berada di bawah tanggungjawabnya, dan mampu mengelola pembelajaran secara mandiri, (10) mampu mendokumentasikan, menyimpan, mengamankan, dan menemukan kembali data untuk menjamin kesahihan dan mencegah plagiasi. Aspek-aspek keagamaan dan kebangsaan sangat dipentingkan dalam rumusan tentang konsep kurikulum di perguruan tinggi. Inilah yang mendasari konten dan pembelajaran berwawasan penguatan masyarakat sipil melalui civic education. 
Materi pendidikan dalam suatu tindak pembelajaran erat kaitannya dengan tujuan yang divisikan oleh suatu lembaga pendidikan yang merupakan manifestasi visi kebangsaan yang mendidikan nilai-nilai yang disepakati suatu bangsa. Bentuk suatu kurikulum sebagai materi pendidikan akan berbeda dari yang lainnya, karena berbedanya konsep kurikulum yang menjadi acuan. Konsep-konsep kurikulum banyak diwarnai konsep tentang fungsi pendidikan, yaitu (1) pendidikan sebagai bahan lembaga untuk melestarikan budaya, (2) pendidikan sebagai lembaga untuk mengubah budaya, dan (3) pendidikan sebagai lembaga untuk mengembangkan pribadi anak didik (Hermino 2013:15). Materi ajar dalam sistem kurikulum pendidikan Islam di perguruan tinggi keagamaan Islam juga dipengaruhi visi kelembagaan suatu perguruan tinggi, visi kementerian, serta visi pendidikan negara Indonesia.

Adapun mata kuliah yang memuat konten penguatan masyarakat sipil, sekurangnya ada 7, yaitu :

\begin{tabular}{|c|c|c|}
\hline No & Mata Kuliah & Deskripsi \\
\hline 1 & $\begin{array}{l}\text { Pendidikan } \\
\text { Pancasila dan } \\
\text { Kewarganegaraan }\end{array}$ & $\begin{array}{l}\text { Merupakan mata kuliah civic education yang } \\
\text { berlaku di semua program studi dengan fokus } \\
\text { pada kajian tentang politik, sistem bernegara } \\
\text { dan berbangsa Indonesia, termasuk Pancasila, } \\
\text { Undang-undang Dasar Republik Indonesia 1945, } \\
\text { Bhinneka Tunggal Ika, dan Negara Kesatuan } \\
\text { Republik Indonesia }\end{array}$ \\
\hline 2 & $\begin{array}{l}\text { Metodologi Studi } \\
\text { Islam }\end{array}$ & $\begin{array}{l}\text { Merupakan mata kuliah dasar-dasar tentang } \\
\text { metode berislam yang berlaku di semua program } \\
\text { studi, mempelajari Islam sesuai dengan konteks } \\
\text { ruang dan waktu, dalam hal ini memahami } \\
\text { keislaman secara universal dan Islam secara } \\
\text { kontekstual di Indonesia. Ada relasi kuat antara } \\
\text { Islam dan negara yang juga menjadi bagian dari } \\
\text { materi studinya }\end{array}$ \\
\hline 3 & Bahasa Indonesia & $\begin{array}{l}\text { Merupakan mata kuliah yang berlaku di semua } \\
\text { program studi untuk memperkuat identitas dan } \\
\text { sikap keindonesiaan secara baik dan benar }\end{array}$ \\
\hline
\end{tabular}




\begin{tabular}{|c|c|c|}
\hline 4 & $\begin{array}{l}\text { Perbandingan } \\
\text { Agama }\end{array}$ & $\begin{array}{l}\text { Merupakan mata kuliah yang mengkaji tentang } \\
\text { sosiologi agama dan perbandingan antar agama } \\
\text { sehingga menciptakan sikap toleransi dan } \\
\text { kerukunan antar agama }\end{array}$ \\
\hline 5 & Tasawuf & $\begin{array}{l}\text { Merupakan mata kuliah di semua program studi } \\
\text { yang mengajarkan kekhususan Islam dengan } \\
\text { pendekatan sufistik, khususnya tarekat yang } \\
\text { banyak dianut dan diamalkan oleh muslim di } \\
\text { Indonesia }\end{array}$ \\
\hline 6 & Praktikum Ibadah & $\begin{array}{l}\text { Merupakan mata kuliah untuk semua program } \\
\text { studi yang memberikan pembekalan praktis } \\
\text { berbagai kegiatan ibadah, baik mahdhoh maupun } \\
\text { ghairu mahdhoh dan kesesuaian dengan amalan- } \\
\text { amalan keislaman tradisi nusantara }\end{array}$ \\
\hline
\end{tabular}

Pendidikan Pancasila dan Kewarganegaraan sebagai mata kuliah wajib bagi semua program studi, sebagaimana disampaikan oleh Sophya (2016) bahwa "pada semua program studi, termasuk program studi Tadris IPS yang saya menjadi tim penyusun kurikulumnya, sudah pasti ada mata kuliah Pancasila dan Kewarganegaraan. Mata kuliah ini sangat terkait dengan mahasiswa agar mempunyai wawasan tentang Pancasila secara baik dan benar, serta agar mahasiswa sebagai insan Indonesia mempunyai keyakinan tentang ideologi negara yang dianut oleh Negara Kesatuan Republik Indonesia”. Salah satu buku yang menjadi rujukan dalam civic education adalah buku Pendidikan Kewarganegaraan (Civic Education) : Demokrasi, Hak Asasi Manusia Dan Masyarakat Madani yang ditulis oleh Dede Rosyada. Buku ini menjadi referensi utama karena dari sisi konten maupun pembelajarannya relevan dengan yang divisikan dari pembelajaran kewarganegaraan yaitu peserta didik yang menjadi insan Indonesia yang berkehidupan keagamaan yang baik dan berkehidupan kebangsaan yang baik pula, atau dengan kata lain agar menjadi warga negara yang agamis dan nasionalis.

Metodologi Studi Islam juga menjadi mata kuliah pembuka bagi semua studi tentang keislaman. Banyak sekali materi-materi keislaman yang harus ditempuh oleh mahasiswa selama kuliah, misalnya ulumul qur'an, ulumul hadits, tafsir, syarhu al-hadits, ilmu tauhid, tasawuf, ushul fiqh, fiqh, dan sejarah peradaban 
Islam. Sebelum mahasiswa mempelajari materi-materi kajian keislaman itu, mereka mendapat pengantar tentang studi Islam secara metodologis. Hal ini sangat penting karena akan melandasi cara berpikir dan cara bersikap, serta cara berperilaku atas ajaran Islam yang moderat dan rahmatan lil alamin. Berpikir Kontekstual, Menangkal Radikal, Menumbuhkan Kesalehan Sosial (2013). Buku ini menjadi bacaan wajib bagi studi Islam di STAIN Kudus. Sebagai contoh cara berpikir tentang poligami. Ulama yang tidak mengakui poligami berpendapat bahwa sesungguhnya Islam berprinsip monogami dan mengecam praktik poligami sebagai perpanjangan tradisi arab pra-Islam yang memberikan status dan kedudukan yang sanagat dominan kepada kaum lakilaki atau male-centris. Sedangkan ulama yang menerima poligami karena memang ada teks (nash) dalam al-Quran yang jelas-jelas membolehkannya (Umar 2014:158). Dalam kajian metodologis, persoalan poligami tidak hanya pahami dengan pendekatan tekstualis saja, tetapi lintas disiplin keilmuan misalnya sosiologi dan hukum serta tradisi-tradisi yang mendahului yang pernah ada dan/atau masih berlaku di suatu daerah. Dengan kata lain, Islam dipahami tidak hanya dengan teks saja, tetapi dengan konteks kehidupan masyarakatnya. Sebagai ilustrasi, bahwa dengan adanya kodifikasi al-Qur'an maka teks kitab suci ini menjadi korpus tertutup dan terbatas. Padahal, problem umat manusia begitu kompleks dan tidak terbatas. Ini meniscayakan para mufassir untuk selalu berusaha mengaktualkan dan mengkontekstualisasikan pesan-pesan universal al-Qur'an ke dalam konteks partikular era kontemporer. Hal ini hanya dapat dilakukan jika al-Qur'an ditafsirkan sesuai dengan semangat zamannya, berdasarkan nilai dan prinsip-prinsip dasar universal al-Qur'an (Mustaqim 2010:55). Tujuan dari mata kuliah dengan konten metodologis adalah agar mahasiswa kelak menjadi sarjana yang mampu berfikir secara rasional dan sistematis serta bersikap moderat sebagai orang beragama Islam, bahkan menyadari bahwa Islam harus dikembangkan secara kontekstual dengan masyarakatnya.

Bahasa Indonesia sebagai mata kuliah wajib memang secara nasional harus diajarkan di semua jenjang pendidikan, termasuk pada jenjang perguruan tinggi. Bahasa Indonesia 
menjadi materi ajar yang membekali mahasiswa agar mempunyai identitas keindonesiaan secara baik dan benar, terutama dalam tradisi dan etika berbahasa. Bahasa Indonesia akan menjadi bahasa pengantar berkomunikasi secara lisan maupun tulisan oleh para mahasiswa dan seluruh warga negara Indonesia. Bahasa Indonesia diajarkan oleh dosen yang menguasai dengan baik kaidah dan praktik berbahasa Indonesia sehingga mahasiswa bisa mempelajari dan menggunakannya dengan baik pula. Amalia (2016), Ketua Program Studi PIAUD mengatakan bahwa "Bahasa Indonesia menjadi materi wajib bagi semua mahasiswa dan semua jurusan, karena di samping bahasa asing, yaitu Bahasa Arab dan Bahasa Inggris, maka mahasiswa Indonesia harus benarbenar menguasai dengan baik penggunaan Bahasa Indonesia. Bahasa Indonesia juga menjadi landasan kepribadian berbangsa Indonesia, jadi baik lisan maupun tulisan, bahasa Indonesia harus dikuasai dengan baik. Lebih dari itu, mahasiswa pada akhirnya juga akan menyusun skripsi dengan bahasa Indonesia, meskipun dibolehkan juga menyusun skripsi dengan bahasa asing lainnya”. Tujuan dari pembelajaran mata kuliah ini adalah agar mahasiswa sebagai warga negara Indonesia mempunyai identitas kebangsaan, berbahasa Indonesia dengan baik dan benar, serta bangga sebagai masyarakat sipil yang berbangsa Indonesia.

Perbandingan Agama sebagai mata kuliah yang terkhusus pada program studi Pendidikan Agama Islam. Asal muasal mata kuliah ini berasal dari kajian akademik dan masukan dari Kementerian Agama, yang memberikan saran bahwa para calon guru agama harus mengetahui perbandingan agama, agar mempunyai komparasi bahwa Islam adalah yang paling benar, akan tetapi juga menghormati dan bersikap toleran kepada agama lain. Susanti (2016) menyatakan bahwa "sebagai pimpinan Program Studi Pendidikan Agama Islam saya dan tim merumuskan adanya mata kuliah Perbandingan Agama sebagai bekal para calon guru agama Islam. Mereka tidak hanya tahu tentang ajaran Islam, tetapi juga mengerti dengan baik sistem dan dasar-dasar ajaran agama lain. Dengan begitu, para guru agama kelak akan mengajarkan kebernaran agama Islam dan toleransi kepada agama lain. Di samping itu, mata kuliah ini pernah disarankan dari pihak luar, 
yaitu pimpinan Kementerian Agama”. Tujuan dari pembelajaran mata kuliah ini adalah agar mahasiswa memahami dengan sebaiknya-baiknya ajaran agama Islam, tetapi tahu dengan pasti bahwa kehidupan antar umat beragama apalagi yang lintas keimanan adalah suatu fakta yang ada dan harus ditumbuhkan rasa toleransi kemanusiaan.

Tasawuf sebagai mata kuliah khusus menjadi wajib di tingkat perguruan tinggi, dalam hal ini diwajibkan di semua program studi. Tasawuf merupakan perpaduan antara ilmu akidah yang membahas hakekat dari keimanan dan akhlak yang membahas tentang sikap dan perilaku terpuji manusia muslim. Tasawuf sebagai mata kuliah, merujuk kepada buku ajar yang sangat terkenal di dunia tasawuf, yaitu kitab Al-Hikam yang ditulis oleh Syeh Ahmad bin Athaillah As-Sakandary. Dalam kitab itu, ada ratusan hikmah yang menjadi nilai-nilai kesufian untuk ikhlas dan mendekat kepada Allah. Hikmah dari al-Hikam itu dimulai dengan hikmah awal, yaitu "min 'alamatil i'timadi 'alal'amali nuqshanurrajai 'inda wujudizzalali” yang berarti bahwa di antara tanda-tanda seseorang bertumpu pada kekuatan amal usahanya ialah kurangnya pengharapan ketika adanya kehinaan dosa, dan kemudian di bagian akhir ada hikmah, yaitu "lau la mayadinunnufusi ma tahaqqaqa sairussairin”, yang berarti bahwa seandainya tidak ada lapangan melawan hawa nafsu, pastilah tidak ada bukti perjalanan orang-orang yang menuju kepada Allah. Tujuan pembelajaran mata kuliah ini adalah agar mahasiswa memahami hakekat beragama Islam, sehingga ada keseimbangan antara hakekat dan syariat agar memahami keislaman secara komprehensif.

Praktikum ibadah sebagai mata kuliah wajib di semua program studi juga mempunyai konten yang sangat penting terkait dengan prosedur dan praksis peribadatan yang didemonstrasikan, disimulasikan, dan dipraktikkan dalam pembelajaran dan secara kontekstual merupakan praktik ibadah yang berkaitan dengan amalan-amalan keseharian serta tradisi-tradisi keagamaan di daerah sekitar kampus yang menjadi basis asal muasal mahasiswa. Dengan kata lain, praktik ibadah yang diajarkan mempunyai beberapa pendekatan, yaitu pendekatan praktis, sosiologis, 
dan kultural. Misalnya, kebanyakan mahasiswa sebagai peserta didik berlatar belakang dari Nahdlatul Ulama, maka praktikum ibadahnya mengajarkan, melatihkan, dan mempraktikkan amalanamalan ala ahlissunnah waljamaah-nya NU, tetapi praktikum juga memberikan kaifiyah dan praktik ibadah untuk mahasiswa ala Muhammadiyah atau lainnya sesuai latar belakangnya. Termasuk buku ajar yang digunakan juga mengandung isi sesuai dengan pilihan-pilihan tersebut, semisal Buku Fiqh Islam karya Sulaiman Rasjid yang menampilkan beberapa versi kesunnahan membaca doa iftitah, dan juga kesunnahan doa qunut, dan doa tahiyat (Rasjid 2013:84-96). Tujuan pembelajaran mata kuliah ini adalah agar mahasiswa mempunyai sikap dan perilaku yang penuh toleransi meskipun berbeda madzhab dalam mengamalkan nilainilai keislaman. Kehidupan penuh toleransi atas perbedaan itu bersifat mendasar dan manusiawi serta memberikan harmonisasi di masyarakat.

Sistem pembelajaran untuk beberapa mata kuliah tersebut dengan didasarkan pada penguasaan kompetensi, tujuan, indikator, strategi dan evaluasi pembelajaran. Kompetensi yang harus dicapai adalah kemampuan untuk memahami dan bersikap secara benar sebagai warga negara Indonesia yang berketuhanan Yang Maha Esa dan cinta tanah air dan bangsa. Pembelajarannya berorientasi konstruktivistik yang bertumpu pada keaktifan belajar mahasiswa melalui kegiatan diskusi, eksplorasi, komunikasi dengan berfikir kritis, analitis dan sintesis dibantu dengan pemanfaatan berbagai sumber belajar. Pelaksanaan perkuliahan dengan pendekatan yang digunakan lebih mengedepankan participatory dan andragogi. Pendekatan individual, kelompok, konsep dan proses, konstruktif, dan deduktif-induktif juga dipergunakan. Metode pembelajaran yang diterapkan adalah metode ceramah, simulasi, diskusi, demonstrasi, peer-teaching, dan praktik. Sedangkan model pembelajaran yang diterapkan antara lain small group discussion, simulasi, demonstrasi, praktik, discovery learning, selfdirected learning, cooperative learning, collaborative learning, project based learning dan problem based learning. Berdasarkan dokumen naskah akademik kurikulum, model pembelajaran di STAIN Kudus digambarkan sebagai berikut : 


\section{MODEL PEMBELAJARAN}

\begin{tabular}{|c|c|c|c|}
\hline No & Metode/Strategi & Peran Mahasiswa & Peran Dosen \\
\hline 1 & $\begin{array}{l}\text { Small Group } \\
\text { Discussion }\end{array}$ & $\begin{array}{l}\text { Membentuk kelompok } \\
5-10 \text { orang, memilih } \\
\text { bahan diskusi, } \\
\text { memperesentasikan } \\
\text { paper atau karya ilmiah } \\
\text { dan mendiskusikan di } \\
\text { dalam kelas }\end{array}$ & $\begin{array}{l}\text { - Membuat rancangan } \\
\text { bahan dan aturan } \\
\text { diskusi } \\
\text { - Menjadi moderator } \\
\text { dan sekaligus } \\
\text { menyimpulkan pada } \\
\text { akhir sesi diskusi } \\
\text { mahasiswa }\end{array}$ \\
\hline 2 & $\begin{array}{l}\text { Simulasi dan/atau } \\
\text { demonstrasi }\end{array}$ & $\begin{array}{l}\text { Mempelajari dan } \\
\text { menjalankan suatu } \\
\text { peran yang ditugaskan } \\
\text { atau mempraktikkan/ } \\
\text { mencoba berbagai } \\
\text { model yang telah } \\
\text { disiapkan }\end{array}$ & $\begin{array}{l}\text { - Merancang situasi/ } \\
\text { kegiatan yang } \\
\text { mirip dengan yang } \\
\text { sesungguhnya, bisa } \\
\text { berupa bermain peran } \\
\text { atau berbagai latihan } \\
\text { simulasi lainnya } \\
\end{array}$ \\
\hline 3 & $\begin{array}{l}\text { Discovery } \\
\text { Learning dan self- } \\
\text { directed learning }\end{array}$ & $\begin{array}{l}\text { Mencari, } \\
\text { mengumpulkan, dan } \\
\text { menyusun informasi } \\
\text { data yang ada } \\
\text { untuk mendeskripsi } \\
\text { suatu pengetahuan. } \\
\text { Kemudian } \\
\text { merencanakan } \\
\text { kegiatan belajar, } \\
\text { melaksnanakan, dan } \\
\text { menilai pengalaman } \\
\text { belajarnya sendiri }\end{array}$ & $\begin{array}{l}\text { - Menyediakan data } \\
\text { atau petunjuk atau } \\
\text { metode untuk } \\
\text { menelusuri suatu } \\
\text { pengetahuan yang } \\
\text { harus dipelajari oleh } \\
\text { mahasiswa } \\
\text { - Memeriksa dan } \\
\text { memberi usulan } \\
\text { terhadap hasil belajar } \\
\text { mandiri mahasiswa } \\
\text { - Sebagai fasilitator } \\
\text { memberi arahan, } \\
\text { bimbingan, dan } \\
\text { konfirmasi terhadap } \\
\text { kemajuan belajar } \\
\text { yang telah dilakukan } \\
\text { mahasiswa secara } \\
\text { individu }\end{array}$ \\
\hline
\end{tabular}




\begin{tabular}{|c|c|c|c|}
\hline 4 & $\begin{array}{l}\text { Cooperative } \\
\text { learning }\end{array}$ & $\begin{array}{l}\text { Membahas dan } \\
\text { menyimpulkan } \\
\text { masalah/tugas yang } \\
\text { diberikan dosen secara } \\
\text { berkelompok }\end{array}$ & $\begin{array}{l}\text { - Merancang dan } \\
\text { memonitor proses } \\
\text { belajar dan hasil } \\
\text { belajar kelompok } \\
\text { mahasiswa } \\
\text { - Menyiapkan suatu } \\
\text { masalah/kasus lain } \\
\text { untuk diselesaikan } \\
\text { oleh mahasiswa secara } \\
\text { berkelompok }\end{array}$ \\
\hline 5 & $\begin{array}{l}\text { Collaborative } \\
\text { Learning }\end{array}$ & $\begin{array}{l}\text { Bekerjasama dengan } \\
\text { anggota kelompok } \\
\text { dalam mengerjakan } \\
\text { tugas, membuat } \\
\text { rancangan proses } \\
\text { dan bentuk penilaian } \\
\text { berdasarkan konsensus } \\
\text { kelompoknya sendiri }\end{array}$ & $\begin{array}{l}\text { - Merancang tugas yang } \\
\text { sifatnya open minded } \\
\text { - Sebagai inspirator, } \\
\text { fasilitator dan } \\
\text { motivator } \\
\text { pembelajaran }\end{array}$ \\
\hline 6 & $\begin{array}{l}\text { Project based } \\
\text { learning dan } \\
\text { problem based } \\
\text { learning }\end{array}$ & $\begin{array}{l}\text { Mengerjakan tugas, } \\
\text { berupa proyek yang } \\
\text { telah dirancang } \\
\text { secara sistematis. } \\
\text { Menunjukkan } \\
\text { kinerja dan memper- } \\
\text { tanggung-jawabkan } \\
\text { hasil kerjanya di } \\
\text { forum. Belajar dengan } \\
\text { menggali atau mencari } \\
\text { informasi/inquiri } \\
\text { melalui pemanfaatan } \\
\text { informasi guna } \\
\text { memcahkan masalah } \\
\text { faktual yang dirancang } \\
\text { oleh dosen }\end{array}$ & $\begin{array}{l}\text { - Merancang suatu tugas } \\
\text { proyek yang sistematis } \\
\text { agar mahasiswa belajar } \\
\text { pengetahuan dan } \\
\text { keterampilan melalui } \\
\text { proses pencarian/ } \\
\text { penggalian informasi } \\
\text { - Menemukan dan } \\
\text { melakukan proses } \\
\text { pembimbingan dan } \\
\text { asesmen } \\
\text { Merancang tugas } \\
\text { untuk mencapai } \\
\text { kompetensi tertentu } \\
\text { Membuat petunjuk } \\
\text { untuk mahasiswa } \\
\text { dalam mencari } \\
\text { pemecahan masalah } \\
\text { yang dipilih oleh } \\
\text { mahasiswa sendiri } \\
\text { atau yang ditetapkan }\end{array}$ \\
\hline
\end{tabular}


Berdasarkan dokumen kurikulum dan observasi lapangan, proses pembelajaran didukung oleh media pembelajaran berbasis teknologi informasi dan komunikasi, laboratorium pembelajaran, laboratorium ibadah, laboratorium bahasa, dan kuliah lapangan di mana masyarakat menjadi laboratorium kerja lapangan. Selain itu dosen dan pengelola merancang dan menyusun instrumen dan perangkat perkuliahan, diantaranya silabus, rencana pembelajaran semester, kontrak perkulihan dan bahan ajar di awal perkuliahan.

Sistem evaluasi atau penilaian menggunakan standar yang tertuang dalam kurikulum pendidikan tinggi berbasis kerangka kualifikasi nasional Indonesia (KKNI) yang mengacu pada Standar Nasional Pendidikan Tinggi (SNPT) bahwa penilaian proses dan hasil belajar mahasiswa dalam rangka pemenuhaan capaian pembelajaran lulusan, penilaian proses dan hasil belajar mahasiswa mencakup: (1) prinsip penilaian, (2) teknik dan instrumen penilaian, (3) mekanisme dan prosedur penilaian; (4) pelaksanaan penilaian, (5) pelaporan penilaian, dan (6) kelulusan mahasiswa. Dalam pelaksanaannya, penilaian menganut prinsipprinsip edukatif, otentik, objektif, akuntabel dan transparan yang dilakukan secara terintegrasi.

Kebijakan penerapan mata kuliah dalam pendidikan Islam yang memuat nilai-nilai pendidikan Pancasila dan kewarganegaraan relevan dengan kebutuhan bangsa Indonesia yang saat ini mengalami tantangan berupa pudarnya nilainilai nasionalisme kebangsaan. Kurikulum yang sesuai standar nasional pendidikan tinggi ini, di samping bermuatan nilainilai nasionalisme juga menguatkan secara ideologi kebangsaan agar masyarakat sipil di Indonesia semakin kuat. Nilai-nilai demokrasi yang bertumpu pada hajat hidup rakyat menjadi tegak dan memberikan kesejahteraan dan kemakmuran. Penguatan masyarakat sipil akan menjamin tujuan negara kebangsaan yang telah lama dicita-citakan sejak lama. Nilai-nilai agama Islam menjadi penguat masyarakat sipil, dan bukan sebaliknya.

\section{Simpulan}

Mata kuliah dan pembelajaran Pendidikan Pancasila dan Kewarganegaraan merupakan pintu masuk pendidikan 
sipil melalui civic education. Mata kuliah dan pembelajaran Metodologi Studi Islam merupakan landasan metodologis untuk memahami Islam dalam konteks nusantara, Bahasa Indonesia untuk menguatkan nilai-nilai identitas kebangsaan dan sikap sosial serta sikap ilmiah, Perbandingan Agama untuk memupuk pemahaman tentang perbedaan dan sikap saling menghormati dan toleransi, Tasawuf untuk menanamkan nilai-nilai hakekat berislam baik secara akidah, secara syariat, maupun secara akhlak, dan Praktikum Ibadah untuk melatih dan membiasakan sikap dan perilaku ibadah yang menghargai perbedaan madzhab dan perbedaan ritual keagamaan. Semua itu merupakan konten yang berisi penguatan masyarakat sipil di Indonesia, terutama terkait pendidikan bagi mahasiswa yang merelasikan antara Islam dan negara, antara penanaman nilai-nilai keagamaan dan kebangsaan, antara nilai-nilai keislaman dan keindonesiaan, antara nilai-nilai ketuhanan dan kemanusiaan.

Pembelajaran mata kuliah yang bermuatan penguatan masyarakat sipil melalui civic education itu didasarkan pada sistem dan prosedur yang berlaku dalam kerangka kualifikasi nasional Indonesia (KKNI) dan standar nasional pendidikan tinggi (SNPT). Orientasi pembelajarannya bersifat visioner terkait dengan relasi keislaman dan keindonesiaan, sehingga memahami Islam dalam konteks keindonesiaan merupakan upaya penguatan masyarakat sipil yang mayoritas muslim agar terhindar dari tindak kekerasan, deskriminasi, dan intoleransi. Jika mayoritas muslim terdidik dengan baik keilmuan keagamaannya, maka perdamaian dan harmoni Indonesia akan selalu terjaga. Pada aspek perencanaan kurikulum, rencana pembelajaran semester, hingga pelaksanaan pembelajaran, dan penilaiannya mengacu pada ketentuan standar. Hasil pembelajaran itu menjadi entri point bagi bahwa pendidikan Islam mempunyai kontribusi yang positif bagi penguatan nilai-nilai nasionalisme kebangsaan, dan pada akhirnya masyarakat sipil di Indonesia semakin kuat untuk menjalankan pembangunan demi kesejahteraan bangsa. 


\section{DAFTAR PUSTAKA}

As-Sakandary, Ibnu Athaillah. Syarh al-Hikam. Surabaya:AlHidayah.

Bogdan, Robert C dan Biklen, S Knopp. 1990. Riset Kualitatif untuk Pendidikan: Pengantar Teori dan Metode. Terjemahan Munandir. Jakarta:Pusat Antar Universitas untuk Peningkatan dan Pengembangan Aktifitas Instruksional Universitas Terbuka.

Bungin, Burhan. 2003. Analisis Data Penelitian Kualitatif: Pemahaman Filososfis dan Metodologis ke Arah Penguasaan Model Aplikasi. Jakarta:PT. RajaGrafindo Persada.

Denzin, Norman, K and Lincold, Yvonna S. 2000. Handbook of Qualitative Research (Second Edition). California:Sage Publication, Inc.

Hermino, Agustinus. 2013. Asesmen Kebutuhan Organisasi Persekolahan : Tinjauan Perilaku Organisasi Menuju Comprehensive Multilevel Palnning. Jakarta:PT. Gramedia Pustaka Utama.

Matthew, Miles B, dan Huberman. 1992. Analisis Data Kualitatif - Terjemahan Tjetjep Rohendi. Jakarta: Universitas Indonesia.

McMillan, James H and Sally Schumacher. 2001. Research In Education A Conceptual Introduction. San Francisco: Longman.

Moleong, Lexy J. 2000. Metodologi Penelitian Kualitatif. Yogyakarta: Rake Sarasin.

Mustaqim, Abdul. 2010. Epistemologi Tafsir Kontemporer. Yogyakarta:LKiS.

Peraturan Menteri Agama Nomor 1 Tahun 2016 tentang Ijazah, Transkrip Nilai, dan Surat Keterangan Pendamping Ijazah.

Peraturan Menteri Agama Nomor 33 Tahun 2016 tentang Gelar Akademik Perguruan Tinggi Keagamaan. 
Peraturan Menteri Pendidikan dan Kebudayaan Nomor 73 Tahun 2013 tentang Penerapan Kerangka Kualifikasi Nasional Indonesia Bidang Pendidikan Tinggi.

Peraturan Menteri Riset, Teknologi, dan Pendidikan Tinggi Nomor 44 Tahun 2015 tentang Standar Nasional Pendidikan Tinggi.

Peraturan Pemerintah RI Nomor 55 Tahun 2007 tentang Pendidikan Agama dan Pendidikan Keagamaan. Jakarta:Direktorat Pendidikan Diniyah dan Pondok Pesantren, Direktorat Jenderal Pendidikan Islam, Departemen Agama RI Tahun 2008.

Peraturan Presiden Nomor 8 Tahun 2012 tentang Kerangka Kualifikasi Nasional Indonesia.

Rasjid, Sulaiman. 2013. Fiqh Islam (Cetakan ke-61). Jakarta:Sinar Baru Algensindo.

Rosyada, Dede. 2003. Pendidikan Kewarganegaraan (Civic Education): Demokrasi, Hak Asasi Manusia Dan Masyarakat Madani. Jakarta:Prenada Media dan ICCE UIN Syarif Hidayatullah.

Sugiyono. 2008. Metode Penelitian Pendidikan Pendekatan Kuantitatif, Kualitatif dan R \& D. Bandung:Alfabeta.

Tim Penyusun STAIN Kudus. 2013. Islam Agama Rahmatan Lil'alamin : Berpikir Kontekstual, Menangkal Radikal, Menumbuhkan Kesalehan Sosial. Kudus: STAIN Kudus.

Umar, Nasaruddin. 2014. Mendekati Tuhan dengan Kualitas Feminin. Jakarta:PT. Elex Media Komputindo.

Undang-Undang Republik Indonesia Nomor 12 tahun 2012 tentang Pendidikan Tinggi.

Undang-Undang Republik Indonesia Nomor 14 tahun 2005 tentang Guru dan Dosen.

Undang-Undang Republik Indonesia Nomor 20 Tahun 2003 tentang Sistem Pendidikan Nasional. Jakarta: Dihimpun oleh Penerbit Asa Mandiri. 
